\title{
Editorial introduction to the China-EU Law Journal special issue on the EU-China Investment Treaty in Interdisciplinary Perspective
}

\author{
Louis Brennan ${ }^{1}$ - Diarmuid Rossa Phelan ${ }^{1}$
}

Published online: 7 July 2016

(C) China-EU School of Law 2016

China has long benefitted from Foreign Direct Investment from western industrialised countries. More recently, spurred by China's "Go Global” encouragement to its firms at the beginning of the last decade, outward bound foreign investment (OFDI) from China has begun to increase rapidly from relatively insignificant levels. In 2010, China's OFDI accounted for slightly in excess of five percent of global OFDI. While still a relatively small share of global OFDI, it is the pace of growth in that share in recent years that has been highly noteworthy. The growth has continued apace in the past few years with China accounting for, in 2013, the third largest share of outward FDI after the USA and Japan. At the November 2014 APEC CEO summit in Beijing, China's President Xi Jinping predicted that China's outbound investment would reach $\$ 1.25$ trillion over the next decade which would see such investment triple over the coming decade. The rapid emergence of China as one of today's leading sources of foreign direct investment in the world is one of the most significant elements of China's economic development.

For the past number of years, there has been active discussion between the EU and China on the conclusion of an investment agreement. This reflects in part the change in the investment relationship between Europe and China. Foreign Direct Investment now not only flows from Europe to China but increasingly, and particularly in recent years, from China to Europe. Under the Treaty of Lisbon, the EU has been granted the competence to engage in this type of negotiation and treaty conclusion, having previously been an exclusive national competence. This is the next stage of EU-China relations and marks a significant development of legal, political, economic and financial significance.

Louis Brennan

BRENNAML@tcd.ie

1 Trinity College Dublin, Dublin, Ireland 
The treaty negotiations are taking place at a momentous time for both the EU and China. The Eurozone is still in the throes of an economic crisis. At the same time, China which for many years experienced double digit economic growth has seen growth slowing in recent years. Both China and the EU have new leadership in place.

Despite the current challenges and changes facing the EU and China, the EUChina relationship remains critically important for the economies of both parties. In fact the current challenges facing both parties suggest that the importance of the relationship is all the greater. This stems from the interdependency that exists in terms of business and economic matters between the EU and China. In the light of such interdependency, the potential benefits of the parties working together to jointly address current challenges are highly significant for each party. Working together in a spirit of mutual cooperation has the advantage of ensuring that actions taken by one party do not work to the detriment of the other. Furthermore, given the significance of the EU and China in the context of the global economy, the maintenance of a harmonious relationship between the two parties is of critical importance for the stability and welfare of the global economy.

China today is the world's largest economy in PPP terms while the EU is the world's single largest market place. Europe's continued prosperity and stability is of vital interest to China. Likewise, China's continued prosperity and stability is of vital interest to the EU.

Thus cooperation between China and the EU is of benefit to both; whilst the opposite is of detriment to both.

The treaty under negotiation improves awareness of the parties' mutual interdependency. The goal should be for both parties to derive benefits.

This special issue is the outcome of our hosting of an international symposium on the EU-China Investment Treaty at the Long Room Hub, Trinity College Dublin in December 2014. The symposium was jointly hosted by the China-EU School of Law (Beijing) and Trinity College Dublin as part of the China-EU School of Law's Symposium Series. The symposium brought to the fore common themes and concerns and, most importantly, a commonality of interest in policies and legal structures. These are captured in this special issue.

The contributors to this special issue reflect a broad span of constituencies from both China and the EU. The contributors are from the worlds of commerce, diplomacy and scholarship.

H.E. David O'Sullivan, EU Ambassador to the United States addresses the China-EU relationship and the significance of the EU-China Investment Treaty. In his response to Ambassador O'Sullivan's contribution, Counsellor Wu Lijun, Charge D'Affaires, Embassy of P.R. China to Ireland also highlights the significance of the proposed Treaty and its benefits to both parties.

Hannah Levinger and Syetam Hansakul offer a panoptic view of the trade and investment relationships between China and the EU in their contribution "China and the EU-Where next in bilateral trade and investment relations?" In his contribution "The EU-China Bilateral Investment Treaty: A challenging first test of the EU's evolving BIT model", David Hallinan assesses the treaty in the context of the EU's evolving Bilateral Investment Treaty (BIT) model while also assessing 
the goals of both parties to the treaty negotiations. Jeremy Clegg and Hinrich Voss in their paper "The new two- way street of Chinese direct investment in the European Union" address the direct investment flows into the EU from China and the potential for progress along a number of dimensions under the Treaty.

In his paper "Practitioners' Perspectives on the China-EU Investment Agreement: Stakeholder Reflections from the Business Community in Beijing", Alan Dukes offers some insights into the perspectives on the Treaty from a practitioner viewpoint. Finally, Kong Qingjiang in his paper "The "State-led economy" Issue in the BIT Negotiations and its Policy Implications for China" considers the matter of the inclusion of state-led economic activities in BIT provisions offering both Chinese and non-Chinese viewpoints.

This special issue offers a diversity of perspectives and viewpoints on the EUChina Investment Treaty. As such, it should contribute to mutual understanding around this important matter. 